\title{
SITUACIÓN ACTUAL \\ DE LA PEDAGOGÍA SOCIAL EN URUGUAY
}

\author{
CURRENT SITUATION \\ OF THE SOCIAL PEDAGOGY IN URUGUAY
}

\author{
SITUAÇÃO ATUAL \\ DA PEDAGOGIA SOCIAL NO URUGUAI
}

\author{
Jorge Camors \\ Universidad de la República, Cenfores (Uruguay)
}

RESUMEN: El presente artículo da cuenta de una línea de investigación documental sobre la realidad educativa nacional y el desarrollo de la educación y de la pedagogía, social, en la Facultad de Humanidades y Ciencias de la Educación de la Universidad de la República, en Uruguay.

Una concepción sobre la educación en sentido amplio y profundo, en base a los desarrollos teóricos que surgen en el Informe Faure de 1972, ampliados luego en el Informe Delors de 1996 y los conceptos de educación para todos a lo largo de la vida y que consideramos muy relevantes los aportes de la educación social y la perspectiva de la pedagogía social para repensar y profundizar la educación y la pedagogía.

De acuerdo a la información y documentación relevada y analizada, hemos podido delinear hasta ahora, tres ejes, de diferente dimensión, que podrían dar cuenta, de la delimitación de nuestro objeto de estudio, en este caso, la Pedagogía Social en Uruguay.

El primero de los ejes es el componente "educativo" en el trabajo profesional de los Asistentes Sociales o Licenciados en Trabajo Social.

El segundo de los ejes, está ubicado en educación formal y precisamente en la escuela.

El tercero de los ejes está relacionado con la evolución en las concepciones educativas en las políticas sociales, particularmente a nivel de infancia y adolescencia y específicamente en el proceso desarrollado a partir de la creación de la figura profesional de Educador Social en Uruguay en 1989.

El trabajo estudia el estado de situación actualmente alcanzado y se detiene especialmente en el impulso que le ha dado a la consolidación de la Pedagogía Social los sucesos en torno al educador social y los desarrollos teóricos y metodológicos desde el Centro de Formación y Estudios (Cenfores), donde se desarrolla la primera etapa de la formación desde 1989 a 2011. 
El trabajo finaliza con reflexiones y conclusiones en relación a la Pedagogía Social en Uruguay, que abren nuevas preguntas para la investigación y pistas para el desarrollo de la formación de los educadores sociales, de la Pedagogía Social, pero fundamentalmente para contribuir al proceso de cambio social y del papel que la educación puede jugar en ello.

PALABRAS CLAVE: Uruguay; política en educación; trabajadores sociales; educación social.

ABSTRACT: This paper shows a documentary research on the national educational reality and the development of education and Social Pedagogy at the Facultad de Humanidades y Ciencias de la Educación of the University of the Republic, in Uruguay.

A conception of education in a comprehensive and deep sense, based on the theoretical developments arising in the Faure Report (1972) later expanded at the Delors Report (1996) and the concepts of education for everybody throughout life, that we consider social education's contributions as relevant and also the perspective of the social pedagogy to rethink and deepen into education and pedagogy.

According to the information and documentation relieved and analysed so far, we have produced three axes of different dimension, that could help us when establishing our object of study; Social Pedagogy in Uruguay.

The "educative" component of the professional work of the Social Workers or Social Assistants is the first axis.

The second axis is the formal education, more precisely at schools.

The third axis is related to developments in social policies' educational conception, particularly during childhood and adolescence, and specifically in the creation of the professional role of the Social Educator in Uruguay (1989).

This work explores the current situation and stops at the Social Pedagogy's consolidation point; what happens around the social work educator and the theoretical and methodological developments coming from the Studies and Training Centre when the fist stage of training began from 1989 to 2011.

The paper finishes with reflections and conclusions related to Social Pedagogy in Uruguay, opening up new questions for research and tracking the development of the social educators' training in Social Pedagogy, but mainly that contribute to social change's process and the education's role on it.

KEYWORDS: Uruguay; politics in education; social workers; social education.

RESUMO: O presente artigo dá conta de uma linha de investigação documental sobre a realidade nacional e o desenvolvimento da educação e da pedagogía social na Faculdade de Humanidades e Ciências da Educação da Universidad de la República, em Uruguai.

Uma concepção sobre a educação em sentido amplo e profundo baseada nos desenvolvimentos teóricos que surgem no Informe Faure de 1972, ampliados logo no Informe Delors de 1996, e os conceitos de educação para todos ao longo da vida consideramos muito relevantes os aportes da educação social e a perspectiva da pedagogía social para repensar e aprofundar a educação e a pedagogía.

De acordo com a informação e a documentação relevada e analisada, podemos delinear, até agora, três eixos, de diferentes dimensões, que poderiam dar conta da delimitação do nosso objeto de estudo, neste caso, a Pedagogia Social no Uruguai.

O primeiro dos eixos é o componente "educativo" no trabalho profissional de Assistentes Sociais ou Licenciados em Trabalho Social.

O segundo eixo está localizado na educação formal e, precisamente, na escola.

O terceiro eixo está relacionado com a evolução das concepções educativas nas políticas sociais, particularmente ao nível de infância e adolescencia e, específicamente, no processo desenvuelto a partir da criação da figur profissional de Educador Social, no Uruguai, em 1989.

[154] JORGE CAMORS

SIPS - PEDAGOGIA SOCIAL. REVISTA INTERUNIVERSITARIA [1139-1723 (2016) 27, 153-178] TERCERA ÉPOCA 
O trabalho estuda o estado da situação atualmente alcançado e se detem, especialmente, no impulso dado pela consolidação da Pedagogia Social diante dos sucesos em torno do educador social e dos desenvolvimentos teóricos e metodológicos desde o Centro de Formação onde se realiza a primeira etapa de formação a partir de 1989 a 2011.

O trabalho finaliza com reflexões e conclusões em relação à Pedagogia Social no Uruguai que abrem novas perguntas para a investigação e postas para o desenvolvimento da formação de educadores sociais, da Pedagogia Social, mas fundamentalmente para contribuir com o processo de transformação social e o papel que a educação pode ocupar nele.

PALAVRAS-CHAVE: Uruguai; política em educação; trabalhadores sociais; educação primária.

\section{1. ¿A qué le llamamos "Pedagogía Social" en Uruguay? Delimitando su objeto de estudio}

\section{Antecedentes}

De acuerdo a la información y documentación relevada y analizada, hemos podido delinear hasta ahora, tres ejes, de diferente dimensión, que podrían dar cuenta de la delimitación de nuestro objeto de estudio, en este caso, la Pedagogía Social en Uruguay.

El trabajo social. El primero de los ejes, constituye un antecedente, que es necesario seguir investigando y que podría ilustrar acerca de algunos acontecimientos posteriores. Se trata del componente "educativo" en el trabajo profesional de los Asistentes Sociales o actuales Licenciados en Trabajo Social.

En el Plan de Estudios, a nivel académico, a partir de 1985, cuando se restablece la democracia en el país y se recupera la autonomía universitaria, se realizaban Talleres de Educación Popular para el trabajo a nivel comunitario de los futuros profesionales.

En 1957 se crea la Escuela Universitaria de Servicio Social que otorgaba el título de Asistente Social, en 1984 se crea la Universidad Católica que otorga el título de Licenciado en Servicio Social y en 1992 se crea la Facultad de Ciencias Sociales que pasa a otorgar el título de Licenciado en Trabajo Social.

Esto se puede explicar posiblemente con el sentido que "lo educativo" tenía, y de alguna manera algo conserva aún, en el perfil profesional del Servicio o Trabajo Social. En este sentido en el año 2013

\section{What do we call "Social Pedagogy" in Uruguay? Defining its object of study}

\section{Background}

According to the information and documentation relieved and analysed so far, we have produced three axes of different dimension, that could help us when establishing our object of study; Social pedagogy in Uruguay.

Social work. The first axis is a precedent, which should be still researched and that could give us information about subsequent events. It is the "educative" component in the professional work of current graduates in Social Work; social workers.

At an academic level, popular educational workshops for future professionals were developed at a community level from 1985, when democracy was restored and the university autonomy was recovered.

The Escuela Universitaria de Servicio Social offered in 1957 the degree of Social Worker. The Social Service degree awarded by the Catholic University was created in 1984 and in 1992 the Facultad de Ciencias Sociales was created offering a degree of Social Worker.

This may possibly be explained given the sense that "educative" had, and somehow the current professional social worker's profile preserves it. In this sense, in 2013 the Association of Social Assistants of the Uruguay (ADASU) disseminated an An- 
la Asociación de Asistentes Sociales del Uruguay (ADASU) difundía un Anteproyecto de Ley de Reglamentación del ejercicio de la profesión de Asistente Sociales Universitario y/o Licenciado en Trabajo Social, que en el artículo $3^{\circ}$ dice: (los subrayados son nuestros)

"Considerase ámbitos de competencia para el ejercicio profesional la investigación y abordaje de las problemáticas sociales mediante la coordinación, el diagnóstico, diseño, ejecución, supervisión y evaluación de proyectos y programas; asesoría e intervención asistencia-socioeducativa, dirigidas a individuos, familias, grupos, organizaciones públicas o privadas, movimientos sociales y comunidades en el marco de las políticas sociales en el Uruguay; así como actividades de docencia, investigación y extensión académicas.

Por tanto, Trabajo Social se desenvuelve en diferentes áreas o campos laborales públicos o privados, tales como el jurídico, la salud, la vivienda, la infancia y adolescencia, la educación, el desarrollo social, entre otras. Es decir, en el marco de la defensa, promoción y garantía de los valores y principios de los Derechos Humanos."

En la ex-Escuela Universitaria de Servicio Social, actualmente integrada a la Facultad de Ciencias Sociales de la Universidad de la República, antes de 1973, uno de los cursos que se dictó era sobre Pedagogía Social, y de acuerdo a la información consignada, el texto de Pablo Natorp integraba su bibliografía.

En síntesis, si bien será necesario profundizar la investigación documental en esta perspectiva, se percibe una formación de nivel universitario y una profesión que se propone incluir el análisis y la reflexión sobre "lo educativo", apoyándose en la pedagogía en general y en la educación popular en particular; en definitiva, un perfil profesional que reivindica la intervención socioeducativa y la educación como parte de su área o campo laboral.

La educación escolar. El segundo de los ejes, lo venimos investigando a partir de los procesos de innovación y cambios que se han venido produciendo en la educación, a lo largo del siglo pasado, concretamente en la educación formal y precisamente en la escuela.

“El último cuarto del siglo XIX significó para el Uruguay la definición de un perfil nacional nítido con teproyecto de Ley de Reglamentación of the Professional Exercise of University for Social Assistant and/or Graduated Social Worker, that states in article 3: (underlined by us)

"They are considered to be competent for a professional research and to face the social problems by coordination, diagnosis, design, implementation, monitoring and evaluation of projects and programs; advice and assistance socio-educational, aimed to individuals, families, groups, public or private organisations, social movements and communities within the social policies framework in Uruguay; as well as the teaching, research and academic extension activities.

Therefore, Social work focuses on several areas or career fields both public and private such legal, health, housing, children and adolescence, education, social development, among others. As to say, within the framework of defence, promotion and guarantee of the values and principles of Human Rights."

In the former Social Service School, now integrated into the Facultad de Ciencias Sociales of the University of the Republic, previous to 1973, one of the issued courses was about Social Pedagogy, and according to the records given, Pablo Natorp's text was part of its bibliography.

In summary, even if it will be necessary to deepen into the documentary research on this perspective, it is perceived as an university level training and a profession that aims to include an analysis and reflection on "educational", relying on pedagogy in general and popular education in particular. In short, a professional profile that demands socio-educational intervention and education as part of its work field.

School education. The second axis is researched from innovative processes and changes occurred in education over the last century, mainly in formal education at school.

"The last quarter of the XIX Century defined the national profile of Uruguay, with a clear vision of colours related to the rest of Latin American countries" (Angione and others, 1987). On those years, a very important part of the Uruguayan education was conceived which will largely explain

[ 156 ] JORGE CAMORS

SIPS - PEDAGOGIA SOCIAL. REVISTA INTERUNIVERSITARIA [1139-1723 (2016) 27, 153-178] TERCERA ÉPOCA 
tonalidades originales en relación a los demás países de América Latina" (Angione y otros, 1987). En estos años se gesta una base muy importante en la educación uruguaya que explicará en gran medida los principales aspectos fundacionales de las principales corrientes de pensamiento, con especial destaque en la primera mitad del siglo XX.

La consolidación del modo de producción capitalista asentado en la producción agropecuaria y en la exportación de materias primas, requería de un sistema político que garantizara una estabilidad en la vida social que trascendiera la estabilidad política de los gobiernos, que finalmente se logra a partir del fin de las confrontaciones políticas a través de las armas, en el año 1904. En este contexto se ubica la reforma educativa que consolidará la figura y el papel de los ciudadanos para el modelo de República que emergía.

La reforma educativa impulsada por José Pedro Varela, aprobada formalmente en 1877 tiene un impacto significativo en la escuela pública y efectos relevantes en otras dimensiones de la educación uruguaya, con una fuerte impronta en las tres décadas siguientes, hasta la reacción conservadora de los años 30'.

El desarrollo de las nuevas ideas pedagógicas se viabilizó en un contexto de fuerte confrontación ideológica entre corrientes liberales y conservadoras, arraigadas estas últimas en sectores de la Iglesia Católica, la prensa y asociaciones civiles.

Además de la ampliación de la cobertura de la enseñanza primaria a nivel nacional, de su proceso de institucionalización y del mejoramiento pedagógico que todo ello implicó, se creó en 1891 el Instituto de Sordomudos, en 1892 el primer Jardín de Infantes y en 1903 los primeros cursos para adultos. Corresponde destacar la significación que tuvo la supresión, en 1909, por ley de "toda enseñanza y práctica religiosa en las escuelas del Estado", consolidando así el pensamiento liberal y progresista en los principales aspectos de la vida nacional en general y en la educación pública en particular.

Una mención especial, indicadora de la confrontación ideológica de la época y elemento integrador de la matriz fundacional del pensamiento pedagógico nacional, se refiere a la promoción de la educación mixta en la reforma educativa que impulsa J. P. Varela. Corresponde destacar la Conferencia dic- the foundational aspects of the main schools of thoughts, particularly in the first half of the $X X^{\text {th }}$ Century.

The consolidation of the capitalist production method based on the agricultural production and the raw material's exportation, (requiring a political system ensuring that social stability will come through governments stability) was finally achieved by ending the political confrontations with firearms in 1904. The educational reform that will strengthen the citizen's role for the emerging Republic happened at that time.

The educational reform boosted by José Pedro Varela (finally adopted in 1877) has a significant effect on public school and on other dimensions of the Uruguayan education, in particular in the next three decades until the conservative reaction in the 30 s.

The development of new pedagogical ideas was possible in a context of ideological confrontations by liberals and conservatives, those ones based on the Catholic Church, the press and civil associations.

A part from broadening the primary education at a national level, its institutionalisation process and the pedagogical improvement drove to the creation of the Deaf Institute (1891) and the first Jardín de Infantes (1982) and in 1903 the first courses for adults. It should be undefined, given the importance of the elimination in 1909 by law "of all religious studies and practices at state schools", so that the liberal and progressive thinking on the main aspects of national life and on public education was consolidated.

The promotion by J.P. Varela of mixed education on the educational reform should be taken as indicative of the ideological confrontations and as an integrative element on the founding matrix of the pedagogical national thought. The conference at the University Club of 1869 on women political rights and the importance of promoting their education to match that of men should be noted.

"The predominant positivism will describe an era of radical transformations", says Arturo Bentancour Díaz in a review for "Brief History of the University of the Republic" (2006) where he describes the conceptual progresses and the importance of the Ley Orgánica passed in 1885 , 
tada en el Club Universitario en 1869 acerca de los derechos políticos de la mujer y la importancia de promover su educación para ponerla a la misma altura intelectual que el hombre.

"El positivismo dominante signaría una etapa de radicales transformaciones" señala Arturo Bentancour Díaz en una reseña redactada para una "Breve historia de la Universidad de la República" en 2006, donde describe los avances conceptuales y la importancia de la Ley Orgánica aprobada en 1885 , donde se desarrollaba la educación media y superior, como una expresión más del contexto y de ese tiempo.

Podemos decir que en esta primera etapa de la educación uruguaya, en seis décadas, se desarrolló un proceso de innovaciones progresistas sustentadas en un ideario liberal, en clara confrontación con las ideas conservadoras presentes en el escenario nacional.

Esta "matriz fundacional" de la educación pública uruguaya, tuvo efectos firmes y relevantes en las dos décadas posteriores. Superado el golpe de estado de 1933 y la nueva Constitución de 1934, se retoma el empuje liberal y progresista sustentado en el desarrollo económico del país, en base a la exportación de materias primas provenientes de la producción agropecuaria y el desarrollo de la industria nacional.

Los primeros efectos que percibimos en la educación son la separación en 1935 de los estudios preuniversitarios de la órbita de la Universidad de la República y la consolidación de la Enseñanza Secundaria. Asimismo en 1942 se crea la Universidad del Trabajo del Uruguay (UTU), retomando algunas ideas del pensamiento de Pedro Figari y continuado las actividades de la enseñanza industrial que se venía desarrollando en el país.

Un enfoque muy significativo de la pedagogía escolar estuvo centrado en la educación rural. Lo más significativo de la época está conformado por la experiencia innovadora de Jesualdo Sosa en la Escuela Rural Canteras del Riachuelo en el departamento de Colonia en el año 1935; las ideas pedagógicas de Agustín Ferreiro en el año 1937 y su propuesta de Escuelas Granjas de 1940; y por último, otro relevante actor de la década del 40' fue Julio Castro, quien siendo Inspector Departamental de Montevideo, es uno de los redactores, junto a Miguel So- where a superior and middle education was developed as an expression of the context and time.

We can affirm that on that first stage of the Uruguayan education (six decades) a process of progressive innovations based on a liberal ideology, confronting the conservative ideas of the national scene was developed.

That "foundational matrix" of the Uruguayan public education had strong effects on the following two decades. After the coup d'état of 1933 and the new Constitution of 1934, the liberal and progressive ideology was recovered based on the country's economic development, mainly on the raw materials from agricultural production's exportation and the national industry development.

The first effect on educations are the separation of the pre-universitary studies form the Universidad de la República in 1935 and the consolidation of the Secondary Education. On the same line, in 1942 the University of Labour of Uruguay (UTU) was created inspired by Pedro Figari's thinking and the industrial education of the country kempt developing.

A very significant focus of the school pedagogy was based on rural education. The most significant of the period was the innovative experience of Jesualdo Sosa in the Escuela Rural Canteras del Riachuelo in Colonia (1935); the pedagogical ideas of Agustín Ferreiro (1937) and his program of Escuelas Granjas (1940); and finally Julio Castro who as Department Inspector for Montevideo was one of the editors along with Miguel Soler and Enrique Brayer of the Rural Schools and Farms' program.

Another highlight for our pedagogy, was characterised by the influence of the fundamental education, ideological thinking developed and promoted by the UNESCO from its beginning.

In Latin America, drove to the creation of the Regional Centre for the Fundamental Education (RCFE), currently named Regional Cooperation Centre for Adult Education in Latin America and Caribbean, which headquarters are in Pátzcuaro, México from where multiple ideas arose through courses and meetings. It was founded in 1950 on the framework of the $4^{\text {th }}$ International UNESCO conference for staff training to develop the principles of the fundamental education focused on

[ 158 ] JORGE CAMORS 
ler y Enrique Brayer del Programa de Escuelas Rurales y Granjas.

Otro impacto muy significativo de la pedagogía de nuestro país, estuvo caracterizado por la influencia de la educación fundamental, pensamiento pedagógico desarrollado y promovido desde la recientemente creada UNESCO a partir de su creación.

En América Latina llevó a la creación del Centro Regional de Educación Fundamental (CREFAL), actualmente denominado Centro de Cooperación Regional para la Educación de Adultos en América Latina y el Caribe, con sede en Pátzcuaro, México y desde donde se irradiaron estas ideas a través de múltiples cursos y encuentros. Fue fundado en 1950 en el marco de la Cuarta conferencia Internacional de la UNESCO para preparar al personal encargado de llevar a la práctica los principios de educación fundamental y que se enfocara la problemática educativa de los grupos marginados desde perspectivas regionales. EI CREFAL abrió sus puertas el 9 de mayo de 1951.

El Primer Núcleo Escolar Experimental de La Mina (PNEEM), fue propuesto por el Maestro Miguel Soler en 1954. El marco teórico pedagógico del Núcleo de La Mina, a partir de un documento de UNESCO editado en París en 1949, "Educación Fundamental. Descripción y Programa" que sirvió de base a la propuesta elaborada para dicho contexto histórico y social (Coronel y Sansón, 1999).

Las Misiones Socio - Pedagógicas a partir del año 1945. En esa fecha se constituye una Sub - Comisión de la Asociación de Estudiantes Magisteriales, vinculados con los Centros Estudiantiles de Medicina y Derecho, de la Universidad de la República. Eran actividades eminentemente asistenciales en esta primera etapa, integrando el trabajo escolar por parte de los estudiantes magisteriales, así como médico, odontológico y agronómico, por parte de los estudiantes universitarios. Se realizaban también actividades culturales, a través de títeres, bailes, canciones, cine y charlas (Moreira, 1968). Estas actividades contemplaban apoyos materiales, como calzado, ropa, juguetes y víveres. Desde el punto de vista de la investigación social, se implementaba un estudio más descriptivo, que denominaban censo, fuertemente sorprendidos y conmovidos por la pobreza encontrada ingresando y recorriendo zonas the educational problems of the marginalised groups from a regional perspectives. The CREFAL was inaugurated the $9^{\text {th }}$ May 1951.

The teacher Miguel Soler (1954) boosted the first Experimental School of La Mina (PNEEM). The pedagogical framework of the Núcleo de la Mina from a UNESCO document published in Paris in 1949, "Fundamental education. Description and Program" enabled an elaborated proposal for the given historical and social context (Coronel and Sansón, 1999).

Socio-pedagogical Missions were created in 1945, since when it was constituted a Sub-Commission of the Asociación de Estudiantes Magisteriales, related to the Schools of Medicine and Law, of the Universidad de la República. A the first stage they were caring activities, integrating the school labour form the magisterial learners with the medical, dental and agronomic by university students. Cultural activities, puppet shows, dances, songs, films and lectures (Moreira, 1968) were performed. Those activities were based on materials as shoes, clothes, toys and food. From the social research viewpoint, the census (a more descriptive research) was implemented given that they were surprised and touched by the poverty of rural areas far form the main urban centres of the country.

According to Oscar Moreira (Coronel and Sansón, 1999), the Socio-Pedagogical Missions' references in Uruguay were the Cultural Missions of México and those of Spain.

“The Socio-Pedagogical Missions' teaching importance over the future teachers leaves no doubt even at that time (today it has changed) that the most part of the future teachers were from middle classes and with remote knowledge of rural life and "rats people" as they were disrespectfully called". On the other hand, it should be noted that most part of teachers working with the PNENM testimonies described their work at the Missions as a way to connect with rural life" (Coronel and Sansón, 1999:21). 
rurales alejadas de los principales centros urbanos del país.

Según Oscar Moreira, (Coronel y Sansón, 1999), las referencias de las Misiones Socio - Pedagógicas en Uruguay fueron las Misiones Culturales de México y las Misiones Socio - Pedagógicas de España.

"La importancia formativa de las Misiones SocioPedagógicas para los futuros docentes creo que es innegable ya que en esa época - ha cambiado en la actualidad - la mayoría de los aspirantes a maestros eran provenientes de clases medias y con poco contacto con la realidad de los rancheríos y pueblos de ratas, como se los llamaba despectivamente. Por otra parte es interesante constatar en la mayoría de los testimonios de los docentes que trabajaron en el PNEEM, su trabajo en las Misiones como elemento relacionador con la realidad rural" (Coronel y Sansón, 1999:21)

\section{El Movimiento de la Escuela Nueva y sus influencias en el pensamiento pedagógico uruguayo}

El antecedente internacional que se considera importante señalar es la definición con un claro enfoque innovador sobre la educación, que se propone en Calais, la Liga Internacional de la Educación Nueva:

"La educación consiste en favorecer el desarrollo lo más completo posible de las aptitudes de cada persona, a la vez como individuo y como miembro de una sociedad regida por la solidaridad. La educación es inseparable de la evolución social, ella constituye una de las fuerzas que la determinan. El objeto de la educación y sus métodos deben ser revisados constantemente a medida que la ciencia y la experiencia aumentan nuestro conocimiento del niño, del hombre y de la sociedad" (Revue Internationale d'education nouvelle, 1922)

En Uruguay, las ideas de la Escuela Nueva, se ubican y desarrollan fuertemente en el marco de un proceso histórico de construcción de la República, con un fuerte papel del Estado en la regulación de los servicios públicos y especialmente de la educación, que tuvo su impulso inicial en la Reforma de Varela.

A estos aspectos políticos, institucionales y ciudadanos, corresponde agregar el proceso económico que se abre paso gracias al desarrollo de las

\section{New School Movement and its influences on the Uruguayan's pedagogical thoughts}

The most relevant international precedent was the definition of a clear innovative focus on education, proposed at Calais, in the International League for New Education:

"Education is about promoting a most complete development on personal skills, both as an individual and as a member of a supportive society. Social development and education come together, as it is one of its main elements. The education aims and methods should be constantly revised as science and human experience increase our knowledge of child, men and society" (Revue Internationale d'Education Nouvelle, 1992).

The New School ideas in Uruguay are located and developed in the framework of an historical process of Republic building, with a dominant state role in the regulation of public services mainly on education, that was initially boosted by Varela's Reform.

Those political, institutional and citizens aspects are the ones adding the new economic process due to the development of communications, infrastructure, domestic and foreign trade, Montevideo's harbour and mainly the two World Wars, when the national production was meant to summoned the non-produced goods on the European countries involved on those conflicts.

Finally, it should be noted that after the end of the II World War some proposals and actions were implemented on the framework of the encouraging economic, social, cultural and political conditions that each country could make.

In our country we made more revitalising proposals for the development of public education, mainly from 1945 to the 6os when the greater process of social and political unrest happened as a result of the international economic changes, work distribution and social sectors reorganisation on power and its ideological supporters. On that sense, we could divide that period on its first stage of boom and the ideology liberalisation 1945-1958; the beginning of changes and greater conflicts 1958-1968; and from there until the pre-dictatorial and repressive era until the coup d'etat of 1973. 
comunicaciones, infraestructura, comercio interior y exterior, el puerto de Montevideo y fundamentalmente las dos guerras mundiales, momentos en los cuales la producción nacional se vio convocada a sustituir los bienes que no se producían y no se podían importar de los países europeos envueltos en la guerra.

Por último, cabe anotar que después de culminada la segunda guerra mundial, se despliegan una serie de propuestas y acciones en el marco de las condiciones generadas favorecedoras del desarrollo económico, social, cultural y político que cada país pudiera formular.

En nuestro país, se dinamizaron propuestas de mayor desarrollo en la educación pública, especialmente en el período 1945 a la década del 60' cuando se inicia un proceso de mayor conflictividad social y política, como consecuencia de cambios en el orden económico internacional, la distribución del trabajo y el reordenamiento de los sectores sociales en el poder y sus correspondientes sustentos ideológicos. En este sentido podríamos subdividir dicho período en una primera etapa de auge y liberalización de ideas entre 1945 a 1958; el comienzo de los cambios y la conflictividad mayor entre 1958 y 1968; y a partir de ese momento el comienzo de la etapa de la represión pre dictatorial hasta el golpe de estado en 1973.

El Movimiento por la Escuela Nueva nació en el año 1954 (Bernassa, 2005), estaba "formado por jóvenes maestros que buscaban colectivamente mejorar sus prácticas y reflexionar sobre ellas".

Más allá de una concepción, propia de la época, en la cual se asemejaba educación a escuela y educador a maestro, deseamos compartir algunos ejes conceptuales que nos dejó a la educación y pedagogía en Uruguay, la reflexión y experiencia del Movimiento de la Escuela Nueva (Bernassa, 2005)

- Había una metodología que proponía una organización institucional en la escuela. Hay un antecedente claro de lo que actualmente se denomina "proyecto institucional de centro educativo".

- Corresponde hacer una mención expresa a la metodología del trabajo en equipo para la conducción del proceso educativo y a la creación del Consejo de Maestros en el centro educativo y en el proyecto.
The New School Movement began in 1954 (Bernassa, 2005) made by “young teachers collectively seeking to improve their lessons and reflect on them".

Beyond a typical conception of the era, where education and school and teacher and educator were resembled, we would like to share some conceptual axis from that Uruguayan education and pedagogy; the reflection and experience of the New School Movement (Bernassa, 2005).

- There was a methodology proposing an institutional organisation of school. That is a clear precedent of what is nowadays called "institutional school project"

-We should mention the teamwork methodology to drive the educational process and the creation of Council of Teachers at schools and in the project.

- The inclusion of the research methodology in that of teachers' professional work in schools. The "situation diagnosis" was essential to the pedagogical action-research process.

- To address the pedagogical and socio-cultural problems an interdisciplinary perspective was considered. First the socio-cultural aspect was taken as part of both problems and solutions, creating an agenda of education professionals. But, meanwhile those professionals were recognised by the new General Law on Education (2008) an explicit germ of what is an educational professional can be find on that Movement.

- Finally, it has to be underlined the importance given to the learning evaluation, related to the project and teamwork, which results were discussed at the Council of Teachers.

To sum up, we could highlight a historical and theoretical pile of reflections, proposals and experiences, on Uruguayan public education, that even though has been focused on "school" as the only way of "performing" a recognised and legitimised education, some contributions made a milestone on the pedagogical platform. Those contributions were adopted when the political, economic, social and cultural accurate conditions came to enrich, enlarge and deepen the education. 
- Había una inclusión de la metodología de investigación en la metodología del trabajo profesional en la escuela por parte de los maestros. Se contemplaba imprescindible el "diagnóstico de situación" vinculado al proceso de investigación - acción pedagógica.

- Para el abordaje de los problemas pedagógicos y socioculturales, se contemplaba la necesidad de una perspectiva interdisciplinaria. En primer lugar se integraba lo sociocultural como parte de los problemas y de las soluciones, integrando la agenda de los profesionales de la educación. Pero si bien esta categoría de profesionales se incluye recién en la Ley General de Educación del año 2008, en este Movimiento había un germen explícito de los perfiles profesionales que "lo educativo" requiere.

- Por último, corresponde señalar la importancia otorgada a la evaluación de aprendizajes, íntimamente vinculada al proyecto y al trabajo en equipo, siendo tema de discusión, los resultados, en el Consejo de Maestros.

En síntesis, podemos destacar una acumulación histórica y teórica, plagada de reflexiones, propuestas y experiencias, en la educación pública uruguaya, que si bien tuvieron su centro en "la escuela" como única modalidad de "hacer" educación, reconocida y legitimada, se dejaron aportes que marcaron a fondo la plataforma pedagógica, sobre la cual, se desplegaron, cuando se dieron las condiciones políticas, económicas, sociales y culturales, adecuadas, para enriquecer, ampliar y profundizar, la educación.

Uruguay sufrió una dictadura cívica - militar desde 1973 a 1984, donde, entre otras cosas, las publicaciones de UNESCO eran consideradas subversivas. La asistencia técnica que se buscaba en UNESCO, a partir de esa época, se empezó a buscar y recibir de los bancos internacionales (BID y Banco Mundial).

Después se vivieron dos décadas de una democracia reconquistada que muchos autores caracterizaron de "tutelada" por los vínculos no totalmente disueltos con el pasado, con los actores y hechos de la dictadura. En la educación escolar (inicial, primaria, media secundaria y técnico - profesional, formación de docentes), si bien en 1985 se aprueba una
Uruguay suffered a civic-military dictatorship (1973-1984) during that period the UNESCO publications were banned. The technical assistance that could not be provided by UNESCO was obtained from international banks (IDB and World Bank).

After that, two decades of democracy came, called by many authors as "a supervised democracy" given the permanent relation between the past (participants and facts of the dictatorship). In the school education (initial, primary, middle, secondary and technical-professional, teaching training) some agreements were taken during two years (a new Law was passed in 1985), but it was called emergency law. That period finally lasted 23 years because from 2005, with the victory of the left side on the elections, parliamentary majorities were obtained in order to approve a new legal, institutional, political and pedagogical framework in 2008 , currently in force.

Given the previously stated and the developed logic, we could affirm that the educational processes and pedagogical reflections are renewed and comforted from neoliberal policies, meeting the best educational traditions, entering a difficult process in order to update and expose education in a broad and deep sense. As it is mentioned on its current regulatory framework, important, interesting, necessary and convenient influences are developed from different theoretical constructs where we can recognise education and social pedagogy.

[ 162 ] JORGE CAMORS

SIPS - PEDAGOGIA SOCIAL. REVISTA INTERUNIVERSITARIA [1139-1723 (2016) 27, 153-178] TERCERA ÉPOCA 
nueva ley, se logran acuerdos por un período de dos años, denominándola ley de emergencia. Ese período finalmente duró 23 años porque es a partir del año 2005 , con el triunfo de la izquierda en las elecciones, se obtienen las mayorías parlamentarias para aprobar un nuevo marco jurídico, institucional, político y pedagógico en el año 2008, actualmente vigente.

Por todo lo anteriormente expresado y la lógica desarrollada, es que se puede decir que los procesos educativos y la reflexión pedagógica se reconforta y se renueva, desde la resistencia a las políticas neoliberales, en el reencuentro con sus mejores tradiciones educativas, incursionando en el difícil proceso de actualización y proyección, de la educación, en un sentido amplio y profundo, tal como se establece en su marco normativo vigente, donde se perciben influencias importantes, interesantes, necesarias y convenientes, desde diferentes perspectivas teóricas, dentro de las cuales reconocemos a la educación y pedagogía social.

\section{El educador en las políticas sociales de infancia y} adolescencia. El tercero de los ejes que hemos venido investigando está relacionado con la evolución en las concepciones educativas en las políticas sociales, particularmente a nivel de infancia y adolescencia y específicamente en el proceso desarrollado en el Consejo del Niño a partir de 1969, interrumpido luego por la dictadura y retomado después de 1985 con particular énfasis desde 1990 al presente.

El Consejo del Niño es la institucionalidad creada por el Código del Niño del año 1934, "como organismo del Estado en relación a la organización jurídico-administrativa del aparato estatal; y desde un punto de vista micro, a las reformas administrativas internas en relación a su estructura organizativa" (García, S. 1997).

La hipótesis básica que orientó el estudio de Socorro García, fue considerar que "las políticas públicas de infancia en nuestro país, históricamente han sido de carácter residual, dirigidas a focos poblacionales, en tanto grupos de "desvío", por lo que implican estrategias fundamentalmente asistenciales y de control social".

El 14 de Setiembre de 1988 se crea el Instituto Nacional del Menor como "servicio descentralizado con personería jurídica y domicilio legal en Monte-
Social policies' educators during childhood and adolescence. The third researched axis is related to education conceptions in social policies, mainly on childhood and adolescence and specifically in the process developed by the Children Council (1969) suspended during the dictatorship and restarted after 1985 particularly from 1990 to the present.

The Children Council is an institution created by the Children Code (1934) "as a State agency related to the legal and administrative organisation; and from the micro point of view, related to internal administrative reforms on the organisation structure" (García, S., 1997).

Its hypothesis was focused on Socorro García's research, considering "the public child policies in our country, to have traditionally being residual, aiming population areas as "detour" groups, and involving primarily caring and social control strategies".

The Minor Institute was created the $14^{\text {th }}$ September 1988 as "a decentralised service with legal status and legal address in Montevideo. The National Minor Institute will substitute the Children Council and will act according to the rules of the Republican Constitution and that Law".

The Children Council School of Officials was created in July 1987 in order to follow the commitment and activities that led to its creations in 1978. The National Education and Studies Center of Vaucresson (France) was inspired on it, and the Youth Protection Educators from the Ministry of Justice of France were trained there.

From 1973-1976 The Children Council School of Officials organises courses for instructors and Regents. Its aim is to train staff responsible for lifelong child and adolescence learning, in the daily life of their boarding schools and day-care centres.

In order to reorganise the institution, it was created the Director of the Officials Schools (1988), currently reopened and it is called to contest for its effectiveness. Finally, myself in January 1989 being Director (after a contest of merits and public examination) I released a work project for the Officials School where the regular training of the educators working with child and adolescents is included in the framework of children social policies. 
video. El Instituto Nacional del Menor sucederá al Consejo del Niño y funcionará de acuerdo a las normas pertinentes de la Constitución de la República y de esta ley".

En Julio de 1987, se reabre la Escuela de Funcionarios del Consejo del Niño, retomando los cometidos y actividades que dieron lugar a su creación en el año 1973. Una de las principales fuentes de inspiración de esta Escuela, fue el Centro Nacional de Formación y Estudios de Vaucresson en Francia, donde se formaban los educadores de la Protección Juvenil de la Justicia del Ministerio de Justicia de Francia.

En el período 1973 - 1976 la Escuela de Funcionarios del Consejo del Niño organiza Cursos para Instructores y Regentes. El propósito era formar al personal a cargo de la educación permanente de los niños, niñas y adolescentes, en la vida cotidiana de los internados y centros diurnos del organismo.

En el año 1988, en el marco de una reestructura institucional se crea el cargo de Director de la Escuela de Funcionarios recientemente reabierta y se llama a concurso para su provisión en efectividad. Finalmente quien suscribe, en enero de 1989 habiendo obtenido el cargo de Director, por concurso de méritos y oposición, presenta un proyecto de trabajo para la Escuela de Funcionarios, donde se incluye en forma destacada la formación regular de educadores para trabajar con niños, niñas y adolescentes en el marco de las políticas sociales de infancia.

Para la formulación de la propuesta de formación de educadores, resultó reconfortante, en el contexto institucional y nacional, encontrarnos con una definición del rol del Instructor, redactada por Alberto Namer en 1973:

“El instructor especializado en jóvenes, es un trabajador social, es un técnico en relaciones humanas, que constituye, en relación constante con otros técnicos del establecimiento, el sostén a la reestructuración y a la expansión de la personalidad, así como a la normalización de las relaciones sociales de los jóvenes que le han sido confiados, principalmente utilizando la relación individual y las interrelaciones de grupos a través de los actos de la vida cotidiana de las diversas actividades desunidas, dirigidas o espontáneas."

En el contexto social e institucional donde se ubica esta caracterización del "instructor" resulta
In order to develop the educator's training proposal, it was comforting, to find at a national and institutional context, with the instructor role's defined by Alberto Namer (1973):

"The young's specialised instructor, is a social worker, a technician in human relations, with a continuous relation with other technicians, supporting the restructuring and expansion of the personality, as well as the normalisation of the teenager relations they work with, mainly by using the individual and interrelationships relations of groups through daily life situations in several unrelated, targeted or spontaneous activities".

At a social and institutional context, the "instructor" is significant and relevant, because the educational job model with interned children and teenagers in a more hospitable than educational focus, recognises the importance of a strong influence of the role in the educational process in fields and based on non-school education strategies. Namer is a psychotherapist, lecturer in the Medicine University and collaborator in Psychiatry of Child and Pediatrics chairs of the Republic University. 
significativo y relevante, porque el modelo de trabajo educativo con los niños, niñas y adolescentes internados con un enfoque más de tipo hospitalario que educativo, se reconoce la importancia de una figura con fuerte influencia en el proceso educativo en ámbitos y en base a estrategias ajenas a la educación escolar. Namer es psicoterapeuta, docente en la Facultad de Medicina y colaborador de las cátedras de Psiquiatría Infantial y Pediatría en la Universidad de la República.

El surgimiento del educador social en Uruguay. El 13 de Setiembre de 1989 el Directorio del INAME aprueba el "Plan de Estudios del Curso Regular de Formación de Educadores" que empezaría a implementarse en Marzo de 1990 con una primera generación, concretamente el 19 de Marzo se lleva a cabo la primera clase. Pocos días después de ser aprobada la propuesta, se le encuentra una denominación a estos futuros educadores. A raíz de la presentación pública del plan de formación, una connotada maestra y psicóloga, con experiencia en el campo de la educación, de la psicología y de la reeducación de las adolescentes en el Consejo del Niño, manifiesta que "serán educadores por la función, y sociales por la problemática con la que trabajen". Esto nos aportó una respuesta y propuesta a la denominación de la nueva figura profesional que surgía en nuestro país: educadores sociales.

Pocos años después, en el marco de las actividades de intercambio y cooperación internacional hispano - uruguayas, se conoce la experiencia española en 1993 y comienzan los contactos en 1996 con el Ministerio de Asuntos Sociales, las Universidades de Barcelona y Salamanca, y la Asociación de Educadores Sociales de Madrid. Estas relaciones de intercambio y cooperación en torno a la formación de los educadores sociales tendrán un trabajo fuerte durante todo el año 1997, dejando una serie de reconocimientos, motivaciones y aprendizajes. En el año 1997 visitan Montevideo por primera vez y comienzan las presentaciones sobre la Pedagogía Social, los amigos y colegas, Violeta Núñez y José Ortega.

La propuesta de formación de educadores sociales desde la Escuela de Funcionarios, que posteriormente adoptó la denominación de Centro de Formación y Estudios, constituyó una factor determinante y un eje estructurante de las reflexiones
The irruption of the social educator in Uruguay. On $13^{\text {th }}$ September 1989, the Directory of the INAME adopts the "Curriculum for the Regular Educator Training Course" whose first generation began at March 1990. Its first lesson was hold the $19^{\text {th }}$ March. Few days after approving the proposal, those future educators where named. As a result of the public release of the training plan, a renowned teacher and psychologist (with expertize in the education, psychology and adolescent re-education fields from the Child Council stated "given their functions they will be educations, and social by the problems they deal". That gave us an answer and proposal for the new professional profile arising in our country: social educators"

Few years' later, in the framework of exchange and international hispanic-Uruguayan cooperation activities, the Spanish experience (1993) is known and the relations with the Ministry of Social Affairs (1996), the University of Barcelona and Salamanca, and the Association for Social Educators of Madrid began. Those exchanges and cooperation relationships in social educators training will be intense during 1997, creating knowledge, motivation and learning. Our friends and colleagues Violeta Núñez and José Ortega first visit Montevideo in 1997 and Social Pedagogy's presentations began.

The Officials School's proposal for social educators training, finally named Centre for Education and Studies, was an essential and also a constructive axis for the pedagogical reflections supporting the educational work of social educators, hired employees acting as educators and all those technicians and professionals working in education, culture and social policies that needed a theoretical and methodological framework that oriented their functions and task accomplishment.

"The Curriculum for the Regular Educator Training Course" (1989) that was the first curriculum of the Social Education Degree in Uruguay, stated: 
pedagógicas que dieran sostén al trabajo educativo de los educadores sociales, de los trabajadores contratados para desarrollar la función de educadores y para todos aquellos técnicos y profesionales que venían trabajando en la educación, en la cultura y en las políticas sociales, que necesitaban un marco teórico y metodológico que les orientara para el desempeño de su función y la realización de sus tareas.

En el año 1989, el "Plan de Estudios del Curso Regular de Formación de Educadores", que finalmente fue el primer plan de estudios de la Carrera de Educación Social en Uruguay, señalaba que:

\section{Existe un rol específico}

Este tipo de funcionario, en la historia del organismo ha sido denominado de diferentes formas: desde el celador y el vigilante, hasta el instructor y especialista en educación del menor.

Lo importante es reconocer que existe un funcionario que por el tipo de tareas que debe desempeñar, debería ser un técnico especializado y por lo tanto, contar con una formación que lo habilite para tal responsabilidad.

Actualmente para tal función no se cuenta con una formación previa de nivel. El diagnóstico que someramente hemos realizado de nuestra propia práctica profesional, reconocer su incipiente desarrollo en nuestro medio y poder llegar a definir y delimitar mejor este perfil de un nuevo técnico que, con una visión social, psicológica y pedagógica, pueda participar a través de la vida cotidiana de los menores, en su respectiva rehabilitación, como parte efectiva de un equipo multidisciplinario.

Una formación teórico-práctica, de nivel terciario, pensada para jerarquizar las potencialidades de un técnico que a través de una relación educativa cotidiana, del vínculo que establece con los menores, pueda mejorar las perspectivas del tratamiento de los menores internados, sino que, en el futuro, pueda incidir desde su rol específico en la prevención."

En el mismo plan de estudios, se desarrollaba el perfil de egreso, de la siguiente manera:

"El Educador Social es el profesional de la educación de atención directa y trabaja en el marco no escolar, con sujetos que, por diversas causas físicas,

\section{There is a specific role}

That kind of official has been named in several ways: from caretaker and steward to instructor and minor education specialist.

The essential matter is to recognise them. Given their performed tasks, they should be specialised technicians, meaning that they need to have a training enabling them for such responsibility.

Nowadays there is no accurate previous training. The brief diagnosis presented from our professional practice, recognise its development in our environment in order to be able to better define and delimit that new technician profile with a social, psychological and pedagogical vision. As to say, being able to participate in minor's daily life, on their rehabilitation as part of an effective multidisciplinary team.

The theoretical and practical training, on a tertiary level, conceived for classifying the technician potentials who through a daily educational relationship, (a link created with the minors) could improve the treatment for the internees minors, and also could influence form their future preventive role.

In the same curriculum, the developed profile was as follows:

"The Social Educator is a educator professional of direct care working in a non-school framework, with individuals that for several physical, psychological and social reasons are in exclusion or unadapted situations.

On the one side, he is a social agent, and on the other, an education professional who needs specific intervention's tools for his job.

- Despite being an educative job, the educators' job is placed between psychological and social areas.

His job basically consists on: supporting the internal development process.

- He helps to connect and manoeuvring enriching the external reality, acting as a bridge, enabling and expanding the social circulation circuit.

This job involves helping out people from marginalisation mental limits. 
psíquicas y sociales se encuentran en situaciones de marginación e inadaptación.

Es, por un lado, una agente social, y por otro, un profesional de la educación que dispone para su trabajo de instrumentos específicos de intervención.

- A pesar de que el trabajo del educador es un trabajo educativo, se sitúa en el punto de articulación entre lo psicológico y lo social.

Su trabajo consiste básicamente en: apoyar el proceso de desarrollo de los concursos internos.

- Ayudar a conectar y a maniobrar de una forma enriquecedora con la realidad externa, haciendo de puente, ayudando a restablecer y a ampliar el circuito de circulación social.

Este trabajo implica ayudar a salir de los límites mentales de la marginación.

El educador social tiene una importante tarea a realizar. Frente a los cambios sociales, debe replantearse nuevas formas de abordar esta tarea, manteniendo buena parte de las características que tradicionalmente son fruto de su trabajo en la vida cotidiana de las Instituciones.

- Tiene que ser capaz de trabajar en el interior de las Instituciones (intentando mejorar sus condiciones) y fuera de ellas: acomodando su práctica de vida cotidiana a marcos abiertos y situaciones cambiantes y a Instituciones en proceso de transformación.

- Como trabajador social debe aprender a situar su práctica respecto a la de otros profesionales que actúan en su mismo campo de trabajo.

- Debe trabajar con instrumentos técnicos específicos "educativos" que le permitan intervenir a nivel individual o de grupo, directamente orientados a permitir y favorecer procesos madurativos individuales y colectivos.

- Debe aprender progresivamente a trabajar en marcos de la vida cotidiana "normal" en las instituciones que enmarcan la vida diaria de la mayoría de los niños. Es esta una nueva necesidad en la medida en que cada vez más, las responsabilidades asistenciales y preventivas serán devueltas a la vida comunitaria.

- Es un técnico capaz de integrar las nociones teóricas en la práctica cotidiana, reconociendo al mismo tiempo su papel específico en el proceso de reeducación a iniciarse o iniciado en el menor.
The social educator has an important task to perform. There should be used new ways of facing social changes, keeping most of their characteristics traditionally resulting from daily life on institutions.

- He should be able to work inside institutions (trying to improve its conditions) and outside them: adapting their everyday life into open environments and changing situations and institutions on transformation processes.

- As a social worker should be able to locate his practice regarding that of other professionals acting in the same work field.

- He should learn to work with the specific technical "educational" instruments allowing him to interact at individual and group level, which is targeted to enable and promote individual and collective maturation processes.

- He must progressively learn how to work in "normal" institutions daily life, which is that of most minors. That is a new need because increasingly the assistance and preventive responsibilities will be returned to community life.

- He is a technician able to integrate theoretical notions in the daily practice, and recognising at the same time his specific role in the re-education process to be launched or started by the minor.

- He should reflect over educational action that can be understood at an institutional level, prior to the reality knowledge, diagnosis and the planning of new projects.

Therefore he should be able to search media, technicians, etc. of learning enabling them to become aware of their continuous training needs in order to adapt their profession to social changes, incorporating at the same time new training and relocating his own educational practice.

- His practice is developed in the framework of daily life form a described, analysed and reflected coexistence. This framework could be found on the institution, on a service, at the street or in "normal life".

- To the extend of being a "cultural transmitter", the social educator should acquire a broad and general vision that enables him to have a deeper 
- Debe reflexionar sobre la acción educativa que puede emprenderse a nivel del medio institucional, previo conocimiento de la realidad, del diagnóstico y de la planificación de proyectos a presentar.

Por tanto debe ser capaz de buscar medios, técnicos, etc. de aprendizaje que le permita tomar conciencia de la necesidad de su formación permanente para ir adaptando su profesión a los cambios sociales, al mismo tiempo que incorpora nuevas informaciones y resitúa su propia práctica educativa.

- Su trabajo se desarrolla en el marco de la vida cotidiana, partiendo de una convivencia calificada, analizada y reflexionada. Este marco lo encontrará tanto dentro de un establecimiento, de un servicio, en la calle o en "el marco de vida normal".

- En la medida que es un "trasmisor cultural", el educador social debe adquirir una visión amplia y general que le permita ser un profundo conocedor de la realidad histórica y cultural de la comunidad, y al mismo tiempo obtener aquellos conocimientos técnicos y herramientas metodológicas que le posibiliten intervenir educativamente a nivel profesional.

- En los últimos años, y en la medida en que se han ido desarrollando los servicios preventivos y de integración, el Educador ha visto abrirse otro ámbito importante para su intervención: los "marcos de vida normal", es decir, centros de jóvenes, centros cívicos, hogares para ancianos... Este ámbito -muy desarrollados en algunos países- es incipiente en el nuestro.

Es importante remarcar que, sea cual sea el ámbito de intervención, el Educador: "utiliza su modelo específico de intervención, con las pequeñas variaciones dadas por la especificidad de cada ámbito".

- Trabaja en equipo. El Educador debe integrarse en el equipo interdisciplinario que aborda cada problemática concreta: asistente social, psicólogo, maestro, trabajador familiar.

- Para poder llevar a cabo su trabajo con eficacia, el educador social como todo profesional, necesita tener la posibilidad de reflexionar y revisar constantemente su práctica. knowledge of the community historical and cultural reality, and at the same time to obtain those technical knowledge and methodological tolls to intervene at a professional level.

- In recent years, and given the development of preventive and integrative services, the Educator has a new area for intervention: the "normal daily life frames", as to say, youth centres, civic centres, elderly centres...that area -well developed in some countries- in ours is just beginning.

It is important to state that whatever the intervention field, the Educator "uses his specific intervention model, with some variations given the particularities of each area".

- He is a team worker. The Educator must be part of an interdisciplinary team facing each specific aspect: social assistant, psychologist, teacher, and family worker.

- In order to be effective at work, the social educator needs to have the possibility to a continuous revision and reflexion on his practice.

- That tells us that his job needs to be planned; make it clear why it is performed, what is its foundation, and its justification. But also planning allows foreseeing what is desired and that can be achieved with his job.

Therefore, the Social Educator must be part of a Project and be trained to create, run and evaluate it within a team"

That list of knowledge, abilities, capacities, ideas and values taken from the documentation from the initial plan for 1989, makes us realise the designed platform to support the social educators performance that constitutes a theoretical and methodological foundational framework for them and for education and (social) pedagogy in Uruguay.

[ 168 ] JORGE CAMORS 
- Esto nos remite a que su trabajo requiere ser planificado, es decir dejar sentado porqué lo realiza, cual es su fundamentación, su justificación. Pero además la planificación permite prever lo que se desea y se puede alcanzar con su trabajo.

Por tanto, el Educador Social debe integrar un Proyecto, y estar capacitado para -dentro del equipo- elaborarlo, ejecutarlo y evaluarlo."

Esta enumeración de conocimientos, habilidades, capacidades, ideas y valores que se ha desarrollado y extractado de la documentación del plan inicial del año 1989, nos permite apreciar la plataforma pensada para sustentar la actuación profesional de los educadores sociales y que constituye un marco teórico-metodológico fundacional para estos actores y para la educación y la pedagogía (social) en Uruguay.

\section{Estado de situación del "objeto de estudio" de la Pedagogía Social}

La Pedagogía Social como disciplina se conoce como disciplina a mediados de los años 90' en Uruguay, a partir de los intercambios con las Universidades de España donde se desarrollaba la carrera de educación social.

En Uruguay, si bien teníamos plena conciencia de la insuficiencia de la figura del maestro, profesor o docente para actuar en los términos conceptuales y prácticas de la educación, concebida en sentido amplio y profundo, cuando se propone la creación de una nueva figura profesional para dar cuenta de esas respuestas y propuestas a los problemas y necesidades de la sociedad, se busca una reflexión pedagógica, que no se encuentra desarrollada en nuestro medio.

\section{Nos encontramos en los años 90', con una pedagogía pensada y desarrollada para la escuela y con una disciplina muy próxima, "pegada" a la didáctica}

Sin desconocer la importancia de la educación popular, la educación física, recreación y campamentos, y luego el desarrollo de la animación sociocultural, vamos a tomar como "eje" del desarrollo de la Pe-

\section{Situation of the Social Pedagogy's “ object of study"}

Social Pedagogy was known as a discipline in the mid-90' in Uruguay, from exchanges with universities in Spain where there were a social education degree.

In Uruguay, although we were fully aware of the inadequacy of the teacher or professor role to act in conceptual terms and education practices, in a broad and deep sense, when the creation of a new professional figure was proposed to organise the answers and proposals to society problems and needs, a pedagogical reflection (not developed in our environment) was seek.

\section{At the 9os we had with a designed and develo- ped pedagogy for school and a very close disci- pline, "glued" to didactics}

Without disregarding the importance of popular education, physical education, recreation and camps, and then the development of socio-cultural animation, let's take the social educators' training as an "axis" for the Uruguayan Social Pedagogy in development.

First of all, it is stated because we have not done enough research on the background and contributions from its practices, experiences, and educational innovations systematisation and the production of pedagogical knowledge to these disciplines of education, practices and different fields, such as popular education, physical education, recreation and camps, and socio-cultural animation, while its contribution to the field is acknowledge.

Secondly, given that those groups political intention around these disciplines were not intended to be projected for achieving an institutional space in those directions, except for physical education, who fought and manage to leave the Superior Institute of Physical Education that first depended on the National Committee of Physical Education of the Ministry of Education and Culture, which was later renamed National Directorate for Sport of the Ministry of Tourism and Sport. In 2002 it was transferred to the Universidad de la República, finally obtaining a place 
dagogía Social en el Uruguay a la formación de los educadores sociales.

Esto lo afirmamos en primer lugar porque no hemos investigado suficientemente los antecedentes y contribuciones desde la sistematización de sus prácticas, las experiencias e innovaciones educativas y la producción de conocimiento pedagógico a estas disciplinas de la educación, prácticas y ámbitos diversos, tales como la educación popular, la educación física, recreación y campamentos, y la animación sociocultural, si bien se reconoce su contribución al campo.

En segundo lugar, porque la intencionalidad política de los colectivos en torno a estas disciplinas no estuvo orientada a proyectarse en lograr un espacio institucional en esas direcciones, excepto la educación física, que luchó y logró salir del Instituto Superior de Educación Física que dependía primero de la Comisión Nacional de Educación Física del Ministerio de Educación y Cultura, que luego pasó a denominarse Dirección Nacional de Deporte del Ministerio de Turismo y Deporte. En el año 2002 se resolvió su pasaje a la Universidad de la República, asentándose finalmente con proyección en la enseñanza, investigación y extensión desde el año 2005 , dentro de la oferta universitaria de nuestro país.

En tercer lugar, los esfuerzos de buscar, pensar y elaborar una pedagogía que trascendiera la perspectiva, íntimamente vinculada a la didáctica, cuyos objetos de estudio fueran los hechos y situaciones de las prácticas escolares, comenzó en la formación de educadores sociales a partir de 1990 en la Escuela de Funcionarios que luego pasó a denominarse Centro de Formación y Estudios, en Montevideo, donde la última generación ingresó en el año 2010. A partir del año 2011 la formación de los educadores sociales se ubicó en el mismo ámbito institucional público donde se venían formando los maestros, profesores de educación media y los maestros técnicos, de la educación formal. Pero además, comenzó a ofrecer cursos en el interior del país, en base a la estructura nacional de la institucional donde se ubicó. Así fue que además de comenzar sus cursos en el Instituto de Profesores "Artigas" (IPA) de Montevideo, se abrieron grupos en el Centro Regional de Profesores (CeRP) en Maldonado (140 KM al este de Montevideo) y en el Instituto de Formación Docente de Artigas $(600 \mathrm{Km}$. al noro- in teaching, research an extension since 2005, within the university offer of our country.

Thirdly, the efforts for seeking, thinking and developing a pedagogy that transcend the perspective, intimately linked to the didactics, whose objects of study were the school practices facts and situations, started in the training of social educators since 1990 at the School of Officers which then became the Education and Studies Centre, in Montevideo where the latest generation started in 2010 . From 2011 the training of social educators stood in the same institutional public sphere where teachers, teachers of secondary education and technical teachers of formal education, were trained. But in addition, it began to offer courses in the interior of the country, based on the national institution structure were it was created. Moreover, to start their courses at the Institute of teachers "Artiga" (IPA) of Montevideo, some groups in the Regional Centre of teachers (CeRP) Maldonado (140 KM East of Montevideo) and the Instituto de Formación Docente de Artigas ( $600 \mathrm{~km}$. Northwest of Montevideo) were opened. Currently there are courses held at the Instituto de Formación Docente de Paysandú $(378 \mathrm{~km}$ to the West of Montevideo), in the Instituto de Formación Docente Treinta y Tres $(286 \mathrm{~km}$ Northeast from Montevideo), in the Institute for Training teachers of Canelones ( $46 \mathrm{~km}$ North of Montevideo). 
este de Montevideo). Actualmente ya se realizan cursos en el Instituto de Formación Docente de Paysandú (378 KM al oeste de Montevideo), en el Instituto de Formación Docente de Treinta y Tres (286 $\mathrm{KM}$ al noreste de Montevideo), en el Instituto de Formación Docente de Canelones (46 KM al norte de Montevideo).

\section{El desarrollo de la educación social en el Uruguay}

La formación de los educadores sociales en el Uruguay, tal como ya se dijo, comenzó en la Escuela de Funcionarios en el año 1990 que en 1995 pasó a denominarse Centro de Formación y Estudios (CENFORES).

La Ley General de Educación No 18.437 de diciembre, 2008, en el art. 31, define que "la formación en educación se concebirá como enseñanza terciaria universitaria y abarcará la formación de maestros, maestros técnicos, profesores, profesores de educación física y educadores sociales, así como de otras que el Sistema Nacional de Educación Pública requiera".

En el siguiente período de gobierno que se instala el 1 de marzo de 2010 comienza el proceso de implementación, habilitando dentro de la Administración Nacional de Educación Pública (ANEP) un nuevo ámbito de nivel terciario en transición a la creación de la Universidad de la Educación cuya creación requiere una ley con mayorías especiales que ya se obtuvieron en una cámara y se encuentra en la agenda del Senado actualmente.

En consecuencia, podemos afirmar que el primer período de la formación, 1990 - 2004 constituyó el momento histórico de la creación de la nueva figura profesional del Educador Social y su vinculación y desempeño en el campo de las políticas sociales y de las políticas educativas.

Las prácticas formativas de los estudiantes de la carrera de educación social durante los primeros años, sin graduados a la vista, constituyeron una muestra y un campo de experimentación y debate en varios frentes: por un lado la propuesta de un enfoque pedagógico diferente al escolar tradicional, demostrando la potencialidad educativa de diversos ámbitos existentes y nuevos, así como la propia vida cotidiana de los espacios sociales, cul-

\section{The development of social education in Uruguay}

The training of social educators in the Uruguay, as noted, began in School Officials in1990 that in 1995 was renamed Centro de Formación y Estudios// Training/Education and Studies Centre (CENFORES).

The General Education Act No. 18.437, December 2008 (article 31) states, "training in education will be designed as university tertiary education and will include the training of teachers, technical teachers, professors, faculty of physical education and social educators and others required by the National System of Public Education".

In the following governmental period from $7^{\text {st }}$ March 2010 the process of implementation begins, enabling a new area of tertiary-level transition to the creation of the University of Education which creation requires a law with special majorities already obtained a camera and is currently on the agenda of the Senate within the National Administration of Public Education (ANEP).

Consequently, we can say that the first training period, 1990-2004 was the historical moment of the creation of the new professional figure of the Social work educator and their bonding and performance in the field of social and education policies.

The training practices of the students of social education degree during the first years, non- graduates, constituted a sample and a field of experimentation and debate on several ways: on the one hand, the proposal of a different pedagogical approaches to the traditional school, showing the educational potential of several existing and new areas, as well as everyday life in social, cultural and sport fields. On the other hand, some professionals were called and threatened by the emergence of a new professional in particular teachers and social workers. Many professionals felt engaged in the theoretical and methodological aspects and in their working practices of their respective programmes and projects; and threatened to the extent that assumed that their job will eventually be at risk.

From 2005, with the creation of the Ministry of Social Development and new public policies boosted by the new Government, many programs and projects that "opened" the perspective theoretical and 
turales y deportivos. Por otro lado, algunas profesiones se sintieron interpeladas y amenazadas por el surgimiento de un nuevo profesional; concretamente Maestros y Asistentes Sociales. Muchos profesionales se sintieron interpelados en los aspectos teóricos y metodológicos y en sus prácticas laborales de sus respectivos programas y proyectos; $y$ amenazados en la medida que suponían que eventualmente se ponían en juego sus puestos de trabajo en las instituciones.

A partir del año 2005, con la creación del Ministerio de Desarrollo Social y las nuevas políticas públicas impulsadas desde el gobierno que iniciaba su gestión, se abrieron muchos programas y proyectos que "abrieron" las perspectivas teóricas y metodológicas, habilitando los aportes de la educación social, y se crearon muchos más puestos de trabajo, para todas las profesiones que podían aportar a las nuevas políticas sociales, educativas y culturales en el país.

Los ámbitos de actuación de los educadores sociales se fueron diseñando a partir de los centros y espacios de la práctica formativa, que luego fueron ocupando los egresados, mediante los llamados públicos que se realizaron. Los logros de la integración de los profesionales y del reconocimiento en la creación de cargos específicos para los educadores sociales se verifican a partir del año 2005. En el INAME, institucionalidad que albergaba a CENFORES y donde nació la propuesta, los cargos recién se crearon en el año 2002 pero se proveyeron en el año 2005.

En síntesis, las resistencias de diferente tipo no fueron menores. Este es uno de los principales factores explicativos del escaso desarrollo de la Pedagogía Social en Uruguay.

Las prácticas formativas y profesionales. Los centros y espacios de las prácticas formativas y profesionales que podemos apreciar desde 1990 a la fecha, son principalmente: los internados de tiempo completo y de protección integral, los centros de privación, y las medidas no privativas, de libertad para adolescentes en conflicto con la ley, los centros de tiempo parcial: clubes de niños en edad escolar y centros juveniles, los equipos de trabajo comunitario en programas de reinserción educativa y de acceso a los programas sociales, los centros y methodological were created, enabling contributions from social education, and many more jobs, for all professions that could contribute to the new social, educational and cultural policies in the country were created.

The action field of social educators were designing from workplaces and educational practice areas, and then the graduates, through public calls were taking the different positions. The achievements of the professional integration and recognition in the creation of specific positions for social educators are verified from the year 2005. In the INAME, institution that housed CENFORES where the proposal was created, positions were created in 2002 but were occupied in 2005.

In short, resistances of different type were not minor. This is one of the major explanatory factors of the underdevelopment of Social Pedagogy in Uruguay.

Training and professional practices. Centres and places for training and professional practices from 1990 up to nowadays, are mainly: internees fulltime and comprehensive protection, centres of deprivation, and the non-custodial measures, for adolescents in conflict with the law, part-time centres: clubs of children in school-age and youth centres, teams of community work programmes of educational reintegration and access to social programs, centres and programs of formal secondary education: secondary and technical - professional, interdisciplinary teams in sex education programs and programs of prevention and addiction of toxic substances, sports, recreation and educational camps, training and job placement projects , among others.

The meetings of teachers and social educators. In addition to the practices of students and graduates, it is necessary and appropriate to mention the Meetings of Educators and Social Educators, promoted and organised by CENFORES.

The first one called educators. Thereafter educators and social educators were convened. The organisation also noted a projection and grading from the initiative and responsibility of CENFORES trainers, first supporting and after as coorganisers, for the two groups: south group 
programas de educación media formal: secundaria y técnico - profesional, equipos interdisciplinarios en programas de educación sexual y en programas de prevención y atención a las adicciones de sustancias tóxicas, plazas de deportes, recreación y campamentos educativos, los proyectos de capacitación e inserción laboral, entre otros.

\section{Los Encuentros de Educadores y Educadores So-} ciales. Además de las prácticas de estudiantes y egresados, es necesario y conveniente mencionar los Encuentros de Educadores y Educadores Sociales, que promovió y organizó CENFORES.

El primero de todos convocó a los educadores. En adelante se convocaban a educadores y educadores sociales. La organización de los mismos también observó una proyección y gradualidad desde la iniciativa y exclusiva responsabilidad de los formadores de CENFORES, primero en calidad de apoyo y luego de co-organizadores, a los dos colectivos: los educadores de Grupo del Sur y los educadores sociales de la Asociación de Educadores Sociales del Uruguay (ADESU). EI VI Encuentro fue organizado por los dos colectivos ya sin la participación de CENFORES.

Los educadores, tal como ya se dijo antes, existían, tenían una función asignada, desarrollaban actividades, tareas, tenían diversas experiencias, y muchos de ellos realizaban interesantes reflexiones. Esa práctica es la que había dado lugar a la creación de una nueva figura y de un marco teórico-metodológico para proyectar una intervención profesional.

Se consideró necesario y conveniente promover los encuentros entre los "viejos" educadores y los "nuevos" educadores sociales, entre quienes estaban en la experiencia, de diferente forma, con aciertos y con dificultades, en general sin formación previa pero, la mayoría de ellos, con grandes deseos de superación, con otros que se estaban formando o que ingresaban a la práctica con una formación. La síntesis era necesaria.

Los Encuentros se desarrollaron de acuerdo a la siguiente cronología:

- I Encuentro Nacional de Educadores - 1997

- Il Encuentro Nacional de Educadores - 10 al 26 de agosto de 1998

- III Encuentro Nacional de Educadores - 9 al 11 de setiembre de 1999 teachers and social educators of the Association of Social Educators of Uruguay (ADESU). The $6^{\text {th }}$ Meeting was organised by the two groups without the participation of CENFORES.

Educators, as mentioned before, did exist and had an assigned function, developed activities, tasks, they had different experiences, and many of them made interesting discourses. This practice had resulted in the creation of a new figure and theoretical and methodological framework for projecting a professional intervention.

We considered it necessary and appropriate, to promote encounters between 'old' educators and 'new' social educators, among those were those with the experience, in different ways, with successes and difficulties, in general without prior training, but most of them, with great desire of overcoming, with others that on training or who starting to practice by training. The synthesis was required.

The meetings were developed according to the following timeline:

- I National Educators' Meeting - 1997

- Il National Educators' Meeting - 10th-26th August, 1998

- III National Educators' Meeting - 9th -11th September, 1999

-IV National Educators' Meeting - 11th - 13th September 2000

- V National Educators' Meeting and Social Educators - 12th-14th September 2001

- VI National Educators' Meeting and Social Educators - November 2002

The Documentation Centre and Library of the Training and Studies Centre has the final published documents on the Meetings II to V inclusive, what constitutes a very important critical mass in the building process of the theoretical - methodological framework for education and social pedagogy in the Uruguay.

SITUACIÓN ACTUAL DE LA PEDAGOGÍA SOCIAL EN URUGUAY [ 173 ] SIPS - PEDAGOGIA SOCIAL. REVISTA INTERUNIVERSITARIA [1139-1723 (2016) 27, 153-178] TERCERA ÉPOCA 
-IV Encuentro Nacional de Educadores - 11 al 13 de setiembre de 2000

- V Encuentro Nacional de Educadores y Educadores Sociales - 12 al 14 de setiembre de 2001

- VI Encuentro Nacional de Educadores y Educadores Sociales - Noviembre de 2002

En el Centro de Documentación y Biblioteca del Centro de Formación y Estudios se cuenta con los Documentos Finales publicados de los Encuentros II al $\mathrm{V}$ inclusive, lo que constituye una masa crítica muy importante en el proceso de construcción del marco teórico - metodológico de la educación y pedagogía social en el Uruguay.

\section{Reflexiones y conclusiones finales}

1. Por todo lo anteriormente expresado, la Pedagogía Social no ha alcanzado aún un fuerte desarrollo disciplinar. No ha habido un lugar claramente identificado en la academia, siendo de reciente data su aparición en cursos para otros profesionales universitarios, además de su inclusión en los planes de formación de los educadores sociales. No ha tenido un fuerte impulso la investigación que le permita conformar una masa crítica importante para nutrir la reflexión teórica, la evaluación de los programas con esta perspectiva educativa y el análisis de las intervenciones y prácticas profesionales. En consecuencia la Pedagogía Social ha tenido escasa incidencia en la formulación de políticas públicas y el diseño de programas y proyectos.

2. No cabe duda que la implementación de la formación de educadores sociales en Uruguay a partir de 1990, contribuyó fuertemente a la revisión crítica de la pedagogía y a la consideración de la Pedagogía Social como una alternativa para repensar la educación, criticarla, reflexionar y elaborar nuevas propuestas y experiencias innovadoras que contribuyeran al desarrollo del campo de la educación.

3. Acerca del objeto de estudio. Inicialmente fueron las prácticas educativas con niños, niñas y adolescentes en los programas y proyectos sociales: internados de protección social, adolescentes con medidas privativas y no privativas de libertad, clubes de niños y centros juveniles. Posteriormente

\section{Reflections and conclusions}

1. Given the above expressed, Social Pedagogy has not yet reached a strong development. It has not find a clear academic place given its recent appearance in courses for other academics, in addition to its inclusion in the social educators' training. The research enabling it to form an important critical mass to nourish the theoretical reflection, the evaluation of programs with this educational perspective and professional practices and interventions analysis has not been strong enough. Consequently Social Pedagogy has had little impact in public policy formulation and in programmes and projects design.

2. It goes without saying that the implementation of the social educators training in Uruguay from 1990, strongly contributed to the critical review of the pedagogy and consideration of Social Pedagogy as an alternative for rethinking education, criticise it, reflect and develop new proposals and innovative experiences that contribute to the development of the education field.

3. The subject of study. Initially they were the educational practices with children and adolescents in programmes and social projects: interned in social protection, adolescents with custodial and non-custodial measures of freedom, clubs for children and youth centres. Subsequently, this educational perspective was gaining ground, and it was convened to participate in other areas of social policy and formal education, becoming formally part in the calls to the interdisciplinary teams and also included in the formulation and design of new programmes and projects, particularly since 2005 , in education and social policies.

4. To sump up, Social Pedagogy is currently a discipline mainly based in Uruguayan social educators' performance, that promotes and enables a reflection on social education, formal and non-formal proposals, as well as promotes and enables a reflection on the educational, social projects and programmes.

5. A methodology in this study of the type of documentary research has been tested, and it should continued and deepened some aspects, such as other

[ 174 ] JORGE CAMORS

SIPS - PEDAGOGIA SOCIAL. REVISTA INTERUNIVERSITARIA [1139-1723 (2016) 27, 153-178] TERCERA ÉPOCA 
esta perspectiva educativa fue ganando terreno y fue convocada a participar en otros ámbitos de las políticas sociales y de la educación formal, llagando a ser incluida formalmente en las convocatorias a llamados a equipos interdisciplinarios, así como incluida en la formulación y diseño de nuevos programas y proyectos, particularmente a partir del año 2005 , en las políticas educativas y en las políticas sociales.

4. En síntesis, podemos decir que actualmente la Pedagogía Social, como disciplina que fundamenta principalmente la actuación profesional de los educadores sociales en Uruguay, promueve y permite una reflexión acerca de lo social de las propuestas educativas, formales y no formales, así como promueve y permite una reflexión acerca de lo educativo, de los programas y proyectos sociales.

5. Se ha ensayado una metodología en este trabajo del tipo de investigación documental, que debe continuar y profundizar en algunos aspectos, tales como otras fuentes que influyeron en el proceso de construcción de la Pedagogía Social en el Uruguay:

- En el campo de la educación: tales como la educación popular, la educación física y recreación incluyendo los campamentos educativos.

- En el campo de otras disciplinas: el desarrollo de la Psicología Social, en particular la concepción operativa de grupos y el análisis organizacional con fuertes articulaciones con la Pedagogía Institucional de Lobrot y Lapassade.

6. El desarrollo alcanzado ha sido significativo, a pesar de las dificultades que debió enfrentar en las dos primeras décadas, cuyos principales aspectos repasamos:

a. Un país fuertemente escolarizado, con una muy rica tradición de aportes de los maestros a la construcción de una escuela pública de libre acceso, ampliamente difundida en todo el país, con prestigio institucional y docente. La experiencia y reflexión educativa acumulada en el país, contribuyó y a la vez presentó obstáculos al desarrollo de una alternativa educativa; no fue fácil de asimilar y al principio se percibió como una amenaza más que como una contribución. sources that influenced the Social Pedagogy in Uruguay's building process:

- In the education field: such as popular education, physical education, and recreation including educational camps.

- Other disciplines: the development of Social Psychology, in particular the operational concept of groups and organisational analysis with strong links with the Institutional Pedagogy of Lapassade and Lobrot.

6. The development has been significant despite the difficulties it has had in the first two decades, whose main aspects we review:

a. A heavily educated country with a very rich tradition of contributions from the teachers to free access' public school, widespread throughout the country, with institutional and academic prestige. The experience and educational thinking in the country contributed and simultaneously presented obstacles to the development of an educational alternative; it was not easy to assimilate and at first was perceived more as a threat than as a contribution.

b. The institutional and programmatic scope of the creation of the new professional figure of the Social Educator was devoted to children and adolescents. This achievement was enclosed by its theoretical, methodological and professional development. Although it allowed it to develop progressively it meant an action framework that initially guided it in a partial and specific direction.

c. The educational policies driven by the Ministry of Education and Culture from 2005, the inclusion of non-formal education and social education in the Educational Debate and National Education Congress in 2006 and the subsequent inclusion of concepts and guidelines in the General Law of Education in 2008, boosted the ideas and experiences that were developing.

d. Recently, from 2011, the social educators' training shares spaces and lives in institutional settings along with the training of teachers and professors of middle education. Again, an achievement presented at the 
b. El ámbito institucional y programático de la creación de la nueva figura profesional del Educador Social fue el dedicado a infancia y adolescencia. Este logro estuvo acompañado de este acotamiento para su desarrollo teórico, metodológico y profesional. Si bien le permitió ir ganando progresivamente un espacio de desarrollo, le significó un marco de actuación que inicialmente lo orientó en una dirección determinada y parcial.

c. Las políticas educativas impulsadas desde el Ministerio de Educación y Cultura a partir del año 2005, la inclusión de la educación no formal y de la educación social en el Debate Educativo y Congreso Nacional de Educación del año 2006 y la posterior inclusión de conceptos y orientaciones en la Ley General de Educación del año 2008, contribuyeron a dinamizar las ideas y experiencias que se venían desarrollando.

d. Recientemente, desde el año 2011, la formación de educadores sociales comparte espacios y convive en ámbitos institucionales junto con la formación de maestros y profesores de educación medial. Nuevamente un logro que a la vez presenta riesgos al poder quedar subsumido por el peso de la tradición y de una acumulación histórica mayor. En la Universidad de la República, la formación en educación nunca ha tenido un espacio relevante y significativo, si bien ha habido una inclusión formal de las Ciencias de la Educación desde los $80^{\prime}$ y una preocupación mayor desde 1992. De todas formas la Educación y Pedagogía Social tienen un lugar tan marginal como la educación en su conjunto en los planes de enseñanza, investigación y extensión de la Universidad de la República.

Para finalizar, quiero agradecer la posibilidad de incluir la perspectiva uruguaya en el amplio y reconocido campo de la Pedagogía Social a nivel internacional, donde desde España, los académicos y la Sociedad lberoamericana han jugado un importante papel de motivación y orientación, así como en América Latina rescatar los incesantes esfuerzos de reflexión e intercambio promovidos desde Brasil. same time risks to be subsumed by the tradition and one greater historical accumulation. At the University of the Republic, training in education has never had a relevant and significant area, although it has been included in Education Sciences from the 80s and more recognised since 1992. Anyway Education and Social Pedagogy have a place so marginal as education as the whole plans of teaching, research and extension of the University of the Republic.

Finally, I want to thank the possibility of including the Uruguayan perspective in the wide and recognised Social Pedagogy filed at international level, where from Spain, the academics and the iberoamerican society have played an important role in motivation and orientation, as well as in Latin America rescuing the relentless effort of reflection and exchange promoted from Brazil.

[ 176 ] JORGE CAMORS

SIPS - PEDAGOGIA SOCIAL. REVISTA INTERUNIVERSITARIA [1139-1723 (2016) 27, 153-178] TERCERA ÉPOCA 


\section{REFERENCIAS / REFERENCES}

Angione y otros, (1987), Dos décadas en la historia de la escuela uruguaya. El testimonio de los protagonistas, Montevideo, Uruguay, Edición de la Revista de la Educación del Pueblo.

Bernasa, J. (2005) El ensayo pedagógico del Movimiento por la Escuela Nueva 1954 - 1958, Montevideo, Uruguay, Impresora Frida.

Bralich, J. (1987), Breve historia de la educación en Uruguay, Montevideo, Uruguay, Centro de Investigaciones y Estudios Pedagógicos.

Camors, J. (1992), Formación de "educadores sociales. Una experiencia en un marco de educación no formal, Montevideo, Uruguay, Revista Rutinas y Rupturas, año II No 3.

Camors, J. (1997), Fundamentos de la acción educativo social", Montevideo, Uruguay, AECl/ Centro de Formación y Estudios.

Camors, J. (1997), La autoridad en el marco de una relación educativa, Montevideo, Uruguay, AECI/ Centro de Formación y Estudios.

Camors, J. (2009), Historia reciente de la educación en Uruguay. Conocer para comprender y transformar, Montevideo, Uruguay, Edit. Grupo Magro.

Camors, J. (2009), A Pedagogia Social na América Latina, en Pedagogia Social, San Pablo, Brasil, Expressao \& Arte.

Camors, J. (2011), Lo social: un campo para recuperar identidades, en Pedagogia Social. Contribuiçòes para uma Teoria Geral da Educaçao Social, San Pablo, Brasil, Expressao \& Arte.

Camors, J. (2012), El Educador Social en Uruguay. Aspectos históricos y fundamentos que explican la construcción de la figura profesional, Montevideo, Uruguay, Edit. Grupo Magro.

CENFORES (2001), La educación social: un marco referencial, en proceso de construcción, para reconceptualizar la función educativa que niños, niñas y adolescentes requieren para ser protagonistas de su tiempo, Montevideo, Uruguay, INAME - Centro de Formación y Estudios.

CENFORES (2003), Hacia la construcción que nos debemos. Una Educación Social para el Uruguay, Montevideo, Uruguay, INAME - Centro de Formación y Estudios.

Carbajal, N. (1993), Agustín Ferreiro. Tradición y vigencia de un educador uruguayo, Montevideo?: Talleres Gráficos de PuntoSur S.A.

Caride, J. A. (2004), Las fronteras de la Pedagogía Social. Perspectivas cientifica e histórica, Barcelona: Gedisa.

Coronel M.H., \& Sansón T. (1999), Primer Núcleo Escolar Experimental de La Mina. Informe Testimonial, Montevideo: Monteverde.

Ley No 9.342 del 6 de abril de 1934.

Ley No 15.977 del 14 de Setiembre de 1988.

Ley General de Educación No 18.437 del 10 de diciembre de 2008.

García Molina, J. (2003), Dar (la) palabra. Deseo, don y ética en educación social, Barcelona: Gedisa.

García, S. (1997), Análisis de los cambios en las políticas públicas de infancia. Retrieved from http://ipes.anep.edu.uy/documentos/

Mialaret, G. (1985), Introducción a las ciencias de la educación, Ginebra, Suiza, UNESCO.

Ministerio de Educación y Cultura (2014), A 140 años de la Educación del Pueblo: Aportes para la reflexión sobre la educación en Uruguay, Montevideo, Uruguay, MEC.

Núñez, V. (1990), Modelos de Educación Social en la época contemporánea, Barcelona: PPU.

Núñez, V. (1999), Pedagogía Social. Cartas para navegar en el nuevo milenio, Buenos Aires: Santillana.

Núñez, V. (2002), La educación en tiempos de incertidumbre; las apuestas de la Pedagogía Social, Barcelona : Gedisa.

Ortega Esteban, J. (1999), Educación Social Especializada, Barcelona: Ariel.

Universidad de la República (2006), Breve historia de la Universidad de la República, Montevideo: Universidad de la República. 


\section{CÓMO CITAR ESTE ARTÍCULO / HOW TO CITE THE ARTICLE}

Camors, J. (2016). Situación actual de la Pedagogía Social en Uruguay. Pedagogía Social. Revista Interuniversitaria, 27, 153-178. DOI:10.7179/PSRI_2016.27.08

Fecha de recepción del artículo / received date: 29.VII.2015

Fecha de revisión del artículo / reviewed date: 25.IX.2015

Fecha de aceptación final / accepted date: 15.X.2015

\section{DIRECCIÓN DEL AUTOR/ AUTHORS' ADDRESS}

Jorge Camors. Facultad de Humanidades y Ciencias de la Educación de la Universidad de la República. Calle Libertad 2635 apto. 003 Montevideo, Uruguay, C.P. 11300 E-mail: jorgecamors@gmail.com

\section{PERFIL ACADÉMICO / ACADEMIC PROFILE}

Jorge Camors. Ingresa a la docencia universitaria en el año 1986. Actualmente es Prof. Adjunto en el Instituto de Educación de la Facultad de Humanidades y Ciencias de la Educación de la Universidad de la República en cursos de grado sobre "Realidad Educativa Nacional" y para graduados de "Pedagogía Social" y de "Educación No Formal". Conferencias a nivel nacional e internacional. Investigaciones y Publicaciones en la temática. Creador de la figura del Educador Social en el Uruguay y primer Director del Centro de Formación y Estudios (CENFORES) en el período 1990 2004. 